\title{
Recycle of Radiologically Contaminated Austenitic Stainless Steels
}

by

K. J. Imrich

Westinghouse Savannah River Company

Savannah River Site

Aiken, South Carolina 29808

D. R. Leader

Westinghouse Savannah River $\mathrm{CO}$.

SC USA

N. C. lyer

M. R. Louthan

DOE Contract No. DE-AC09-89SR18035

This paper was prepared in connection with work done under the above contract number with the U.S.

Department of Energy. By acceptance of this paper, the publisher and/or recipient acknowledges the U.S. Government's right to retain a nonexclusive, royalty-free license in and to any copyright covering this paper, along with the right to reproduce and to authorize others to reproduce all or part of the copyrighted paper. 


\section{DISCLAIMER}

This report was prepared as an account of work sponsored by an agency of the United States Government. Neither the United States Government nor any agency thereof, nor any of their employees, makes any warranty, express or implied, or assumes any legal liability or responsibility for the accuracy, completeness, or usefulness of any information, apparatus, product, or process disclosed, or represents that its use would not infringe privately owned rights. Reference herein to any specific commercial product, process, or service by trade name, trademark, manufacturer, or otherwise does not necessarily constitute or imply its endorsement, recommendation, or favoring by the United States Government or any agency thereof. The views and opinions of authors expressed herein do not necessarily state or reflect those of the United States Government or any agency thereof.

This report has been reproduced directly from the best available copy.

Available to DOE and DOE contractors from the Office of Scientific and Technical Information, P.O. Box 62, Oak Ridge, TN 37831; prices available from (615) 576-8401.

Available to the public from the National Technical Information Service, U.S. Department of Commerce, 5285 Port Royal Road, Springfield, VA 22161. 


\section{DISCLAIMER}

Portions of this document may be illegible in electronic image products. Images are produced from the best available original document. 


\title{
Recycle of Radiologically Contaminated Austenitic Stainless Steels
}

K. J. Imrich, D. R. Leader, N. C. Iyer and M. R. Louthan, Jr.

\begin{abstract}
The United States Department of Energy owns large quantities of radiologically contaminated austenitic stainless steel which could be recycled for reuse if appropriate release standards were in place. Unfortunately, current policy places the formulation of a release standard for U.S. A. industry years, if not decades, away. The Westinghouse Savannah River Company, Idaho National Engineering Laboratory and various university and industrial partners are participating in initiative to recycle previously contaminated austenitic stainless steels into containers for the storage and disposal of radioactive wastes. This paper describes laboratory scale experiments which demonstrated the decontamination and remelt of stainless steel which had been contaminated with radionuclides.
\end{abstract}

\section{INTRODUCTION}

Nuclear materials production facilities owned by the United States Department of Energy (DOE) use large quantities of austenitic stainless steel for structures, piping and components. Typical service conditions cause radiological contamination and/or neutron activation of much of this steel. Recent changes in the global political climate have lead to

*Westinghouse Savannah River Company, Aiken, SC 29808 
significant transitions in mission within the DOE and to an increased emphasis on environmental restoration of many of the previously contaminated areas. Recycle, reuse, waste minimization and environmentally conscious disposal have become key issues in the materials utilization arena. This paper describes portions of an initiative to recycle previously contaminated austenitic stainless steels into containers for the storage and disposal of radioactive wastes. This initiative is part of a cooperative program involving the Savannah River Site, Idaho National Engineering Laboratory and university and industrial partenships.

\section{BACKGROUND}

Decontamination and recycle of radiologically contaminated metals and alloys could significantly reduce the waste volume, conserve national resources and improve the economics of the decommissioning of nuclear installations. However, socio-political considerations must be balanced with technical, safety and economic considerations. This is particularly true in the United States of America and has severely restricted the recycle process. Successful reintroduction of previously contaminated metals into the primary metals industry requires decontamination standards.

The European Union currently recommends a clearance level of $1 \mathrm{~Bq} / \mathrm{g}$ for $b$ and $g$ emitters while Germany recommends a lower level of 0.1 $\mathrm{Bq} / \mathrm{g}$, the United Kingdom $0.4 \mathrm{~Bq} / \mathrm{g}$ and Japan $0.5 \mathrm{~Bq} / \mathrm{g}$. Obviously, internationally accepted limits have not yet been developed; however, even with the lack of international standards the Siempelkamp plant in Germany, Studsvik of Sweden, and smaller plants in Japan and Slovakia have released recycled material into the free market (1). Worldwide trade, international movement of materials and the existing recycle market for non-contaminated metals and alloys assure that when any nation free releases previously contaminated metals and alloys, all nations eventually use and recycle products fabricated from previously contaminated materials. However, the ineffability of using previously contaminated metals in the U. S. A. places the formulation of a release standard for U.S. A. industry years, if not decades, away.

Evaluation of potential for recycling radioactive scrap metal (RCM) (2) in the U. S. A. has shown that: 
a) "the perception of risk related to radioactive materials is more intense in the U.S. than in any other country", and

b) "not recycling RCM involves some trade-off of risk in industrialized countries for environmental and health impacts in developing countries" (presumely because of the environmental impact of mining operations to obtain the chromium necessary to replace that buried).

Apparently, current policies for recycle of radioactively contaminated scrap metal are such that, regardless of actions by most developed nations and the possible detrimental effects to developing nations, free release of RCM from U. S. nuclear facilities, including metals and alloys from DOE sites, is extremely unlikely.

\section{REGULATED REUSE}

The DOE owns large inventories of radioactive scrap metals $(1.5$ million tons), with much of that metal in a current state of storage that presents a future liability to DOE (3). For example, Savannah River Site has, from approximately 35 years of reactor operation, over 68 heat exchangers which are currently stored on pads outside a reactor building. Each heat exchanger is about the size of a railroad car, weights about 100 tons and is fabricated almost entirely from Type 304 stainless steel. Disposition and disposal of these radioactively contaminated heat exchangers can be accomplished through any of several pathways as illustrated in Figure 1.

The "leave on pad", or do nothing, option is not compatible with the environmental restoration initiatives at the Savannah River Site. Even if this long term alternative were environmentally appropriate the cost of continuous monitoring and physical protection of the storage area would become overwhelming. Transfer and burial of the heat exchangers would use a significant fraction of existing Savannah River Site burial ground capacity, reduce future options for reuse of the steel and waste critical materials (e.g. chromium). Therefore, burial may not represent a technically prudent disposal alternative. Decontamination and release of the clean steel into the commercial market would provide the best alternative if the regulatory instruments for such release were in place in the United States of America. Unfortunately, the steel in the heat exchanges contains both internal contamination from internal activation and tritium absorption and external contamination from the 


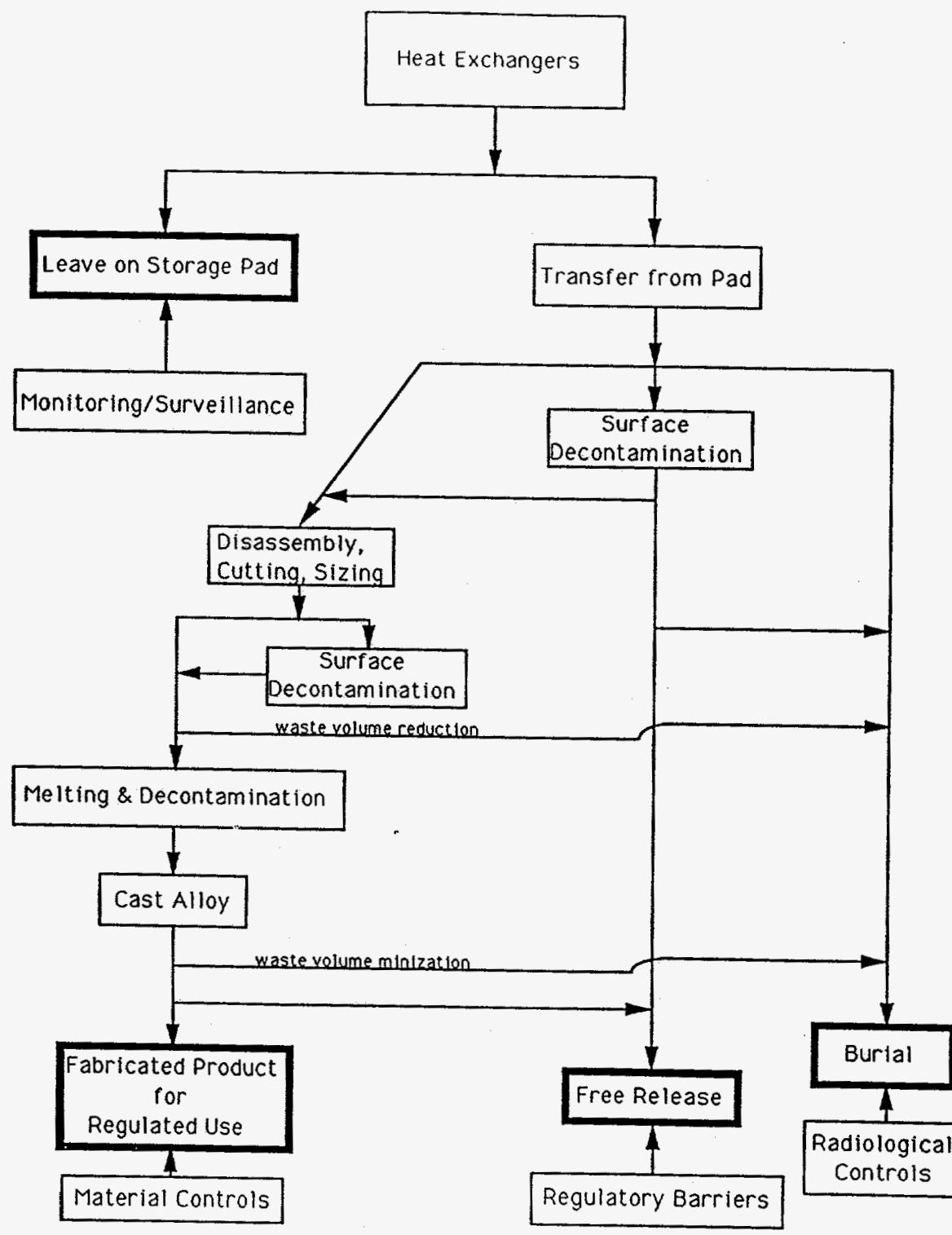

Figure 1. Flow Sheet Illustrating Possible Disposition Pathways for the Hundred Ton, Austenitic Stainless Steel Heat Exchangers Currently Stored at the Savannah River Site 
accumulation of radionuclides on the exposed surfaces. The current regulatory framework provides for the removal of surface contamination but precludes free release of materials that have had any internal contamination. Regulated reuse therefore becomes the only effective alternative for disposal of the heat exchangers.

Regulated reuse involves decontamination and recycle of the steel such as that from the heat exchangers. However, distribution of the recycled steel is severely limited. Current plans are for the recycled steel to be fabricated into containers for nuclear waste. The waste containers will remain under DOE control, thus preventing free release of the steel into a non-regulated market. Advantages of regulated reuse include reducing the need for:

a) burial of contaminated material and

b) the introduction of additional steel into the DOE contaminated metals inventory.

The primary disadvantages of regulated reuse are:

a) the need to maintain continual control over the recycled materials, and

b) the potential difficulty in assuring a market for the components fabricated from the recycled stock.

The Savannah River Site recycle initiative is aimed at demonstrating that radiologically contaminated Type 304 stainless steel components, including heat exchangers from the reactors, can be successfully recycled. Up to two hundred tons of contaminated steel will be decontaminated, remelted, cast and fabricated into boxes and/or drums for the storage of contaminated waste. Although the technology required for stainless steel recycle is well established, recycle combined with decontamination and radiological hazard characterization have not been demonstrated. The Savannah River demonstration will validate the decontamination-recycle combination and provide metallurgical characterization of the recycled material. This paper describes the microstructural characterization of the first few laboratory heats of decontaminated-recycled Type 304 stainless steel. 


\section{MATERIALS AND PROCESSES}

Feed stock for the initial decontamination-remelt demonstrations was small pieces or sections of the piping and heat exchangers which had been removed from the reactor process water systems and metallurgically evaluated $(4,5)$. These sections, which had been decontaminated for metallographic examination. were radiologically characterized and remelted in an induction furnace. The initial melts provided approximately ten pound heats of steel which were sectioned. analyzed and cold rolled. Heats of steel were also prepared from noncontaminated feed stock to facilitate the evaluation processes.

Surface contaminantion was reduced by water rinsing and nitric acid cleaning. Nitric acid decontamination was used because of its compatibility with existing radioactive waste processing technologies at the Savannah River Site. Although nitric acid removes most of the smearable surface contamination, it does not effectively remove contamination that is trapped in surface flaws and cracks (Figure 2) From a practical standpoint the potential for such defects makes the level of effort required to assure complete decontamination of any component removed from reactor service difficult, if not impossible. Therefore, in-melt decontamination will be necessary for the recycle process and was accomplished in the laboratory studies by preferentially trapping radionuclides in a slag over the induction melt. The detailed slag-metal interaction studies necessary to optimize the melt refining/decontamination processes are underway (6).

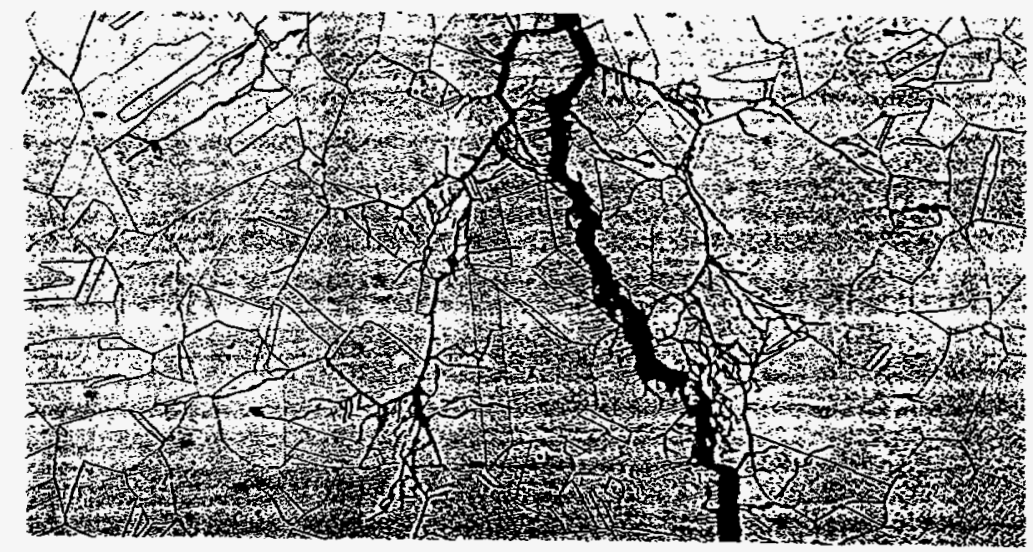

Figure 2. Stress Corrosion Crack in Process Water Pipe from SRS Reactor. (100X) 
Selected pieces of reactor process piping and heat exchangers were melted to approximately $1500^{\circ} \mathrm{C}$, then poured into either metal or sand molds. The ingot-mold system was air cooled to room temperature before the as-cast ingot was removed for evaluation and rolling. Melt offgas was monitored throughout the melt-pour process without indications of radionuclide release. The slag used for these initial studies was borosilicate glass. Transfer of radionuclides into the slag was noted. Two of the three ingots cast from previously contaminated steels showed contamination was undetected by com mon survey methods while one ingot was contaminated to higher levels than anticipated for regulated reuse. Heats of steels from the non-contaminated feed stock were prepared in the facilities used to process the contaminated feed and showed no indications of radionuclide uptake.

Elemental analysis demonstrated that the interior of ingots was an $18 \%$ $\mathrm{Cr}-8 \% \mathrm{Ni}$ alloy even though the exterior surfaces were depleted in chromium and perhaps in nickel. This demonstrated that neither selective oxidation nor slag refining preferentially removed significant quantities of the primary alloying elements. The induction furnace used for these studies was designed to melt metal in a graphite crucible, thus the initial recycle experiments were done in a graphite crucible. This led to significant carbon uptake during the melt-cast process for austenitic stainless steel. The carbon uptake, coupled with the slagging processes resulted in a decontaminated, high carbon "stainless steel". Subsequent tests were done by melting the stainless steel in an alumina or zirconia crucible that was placed inside the required graphite crucible. Use of the alumuna or zirconia crucibles minimized the potential for carbon uptake by direct contact with graphite and led to a successful melt-cast process for Type 304 stainless steel.

\section{MET ALLOGRAPHIC OBSERVATIONS}

Selected sections of the high carbon stainless steel ingot (Figure 3) were prepared for both optical and electron metallography. Energy dispersive analysis of the $\mathrm{x}$-rays created during scanning electron microscopy (Figure 4) confirmed that the interior of the as-cast ingots was of an $18 \% \mathrm{Cr}-8 \% \mathrm{Ni}$ composition. Optical metallography revealed the austenite-ferrite microstructure typical of the cast austenitic stainless steels (Figure 5). A gradient in microstructure from the ingot interior to the ingot exterior was observed. This gradient extended 


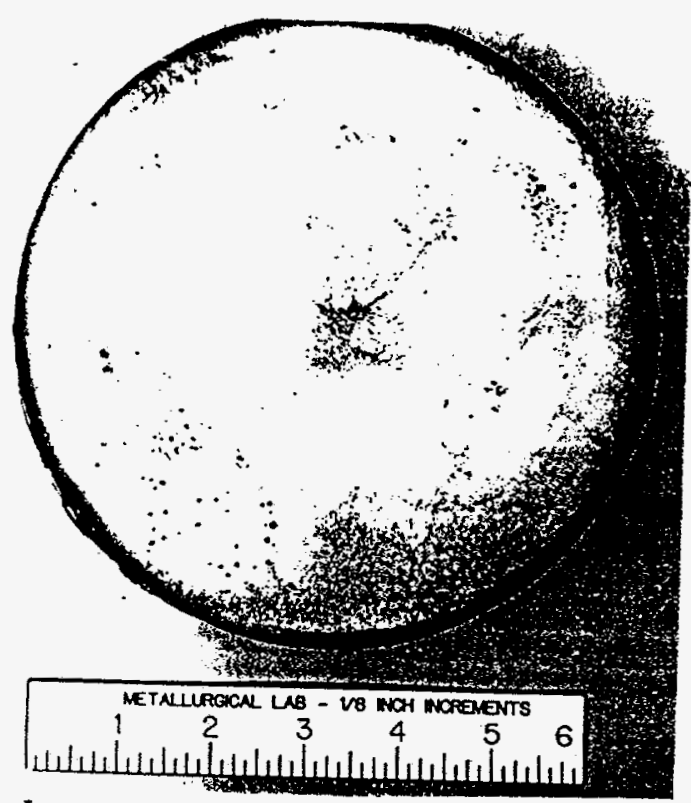

Figure 3. Ingot from Recycled Austenitic Stainless Stee1

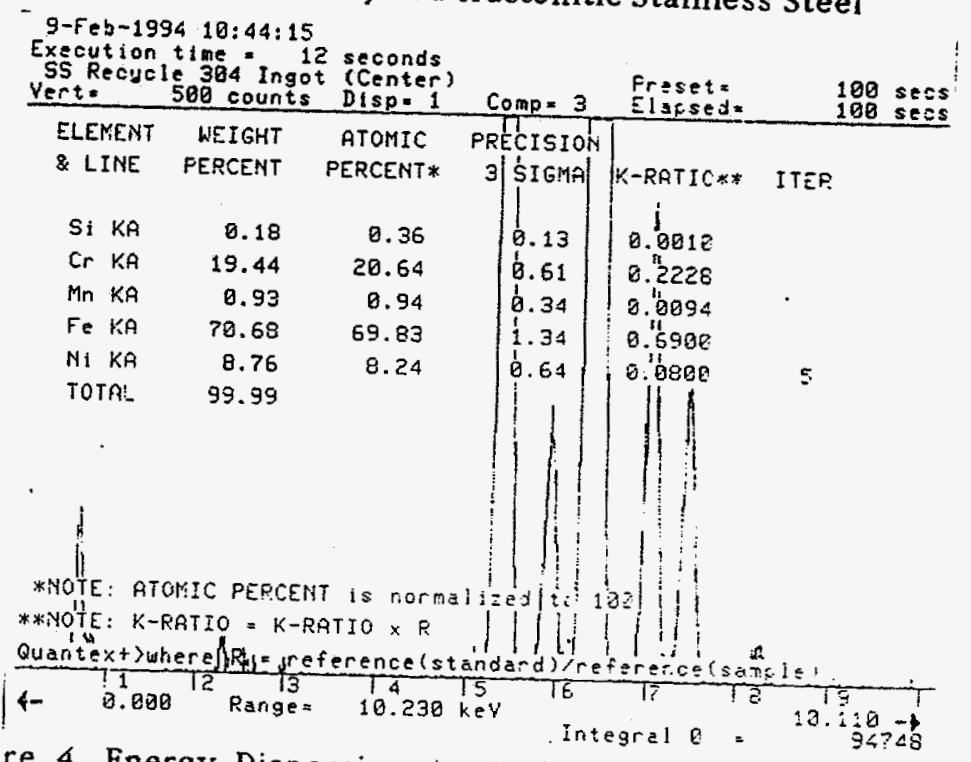
Figure 4. Energy Dispersive Analysis of $X-r$ ays Created during
SEM Examination of Center of Ingot 


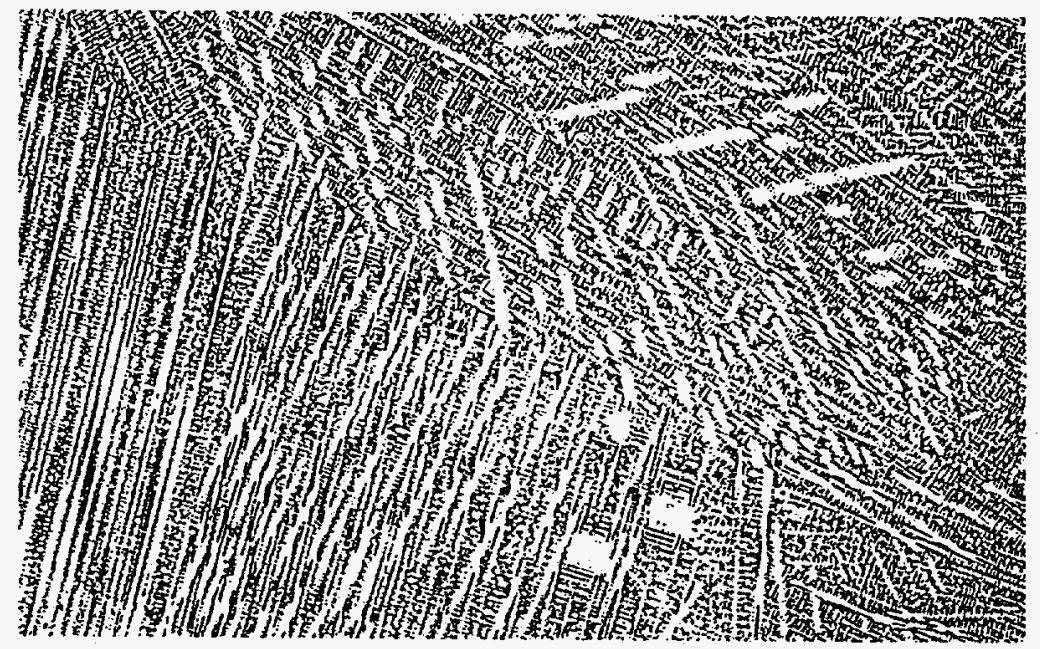

a) Macrostructure at $16 \mathrm{X}$

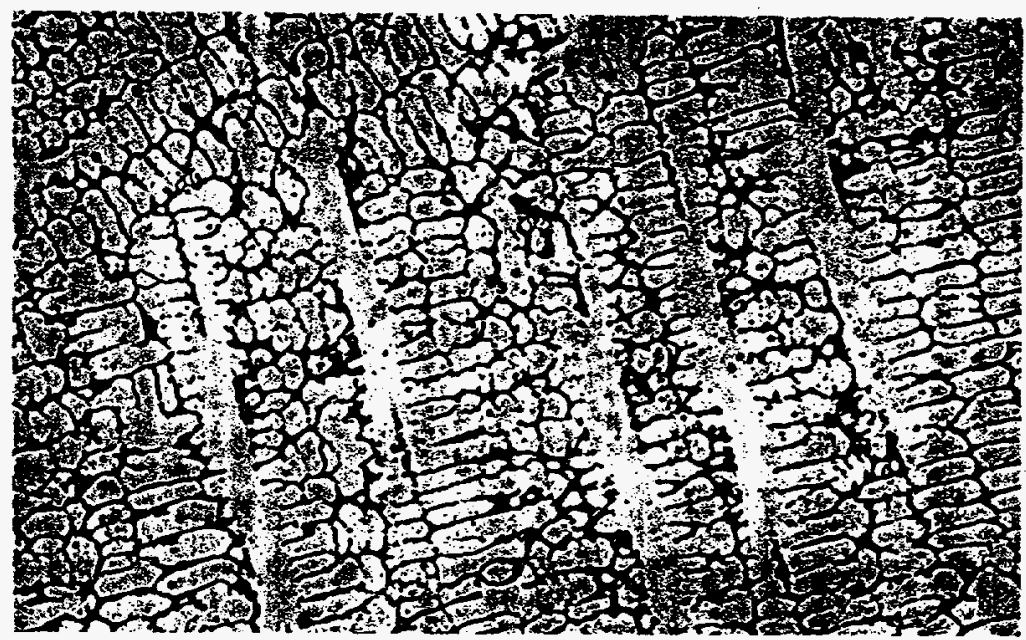

b) Microstructure at $100 \mathrm{X}$

Figure 5. Structure of As-cast Austenitic Stainless Steel Ingot from Recycled Material 
approximately $1 \mathrm{~mm}$ into the ingot (Figure 6) and is associated with a near surface depletion of chromium and perhaps nickel (Figure 7). The location of the depleted region demonstrates preferential oxidation of the chromium during ingot solidification and is consistent with the observation that neither selective oxidation nor slag refining preferentially removed significant quantities of the primary alloying elements during the melting process. Additionally this observation demonstrates the benefit of the slag in preventing oxidation of the underlying metals.

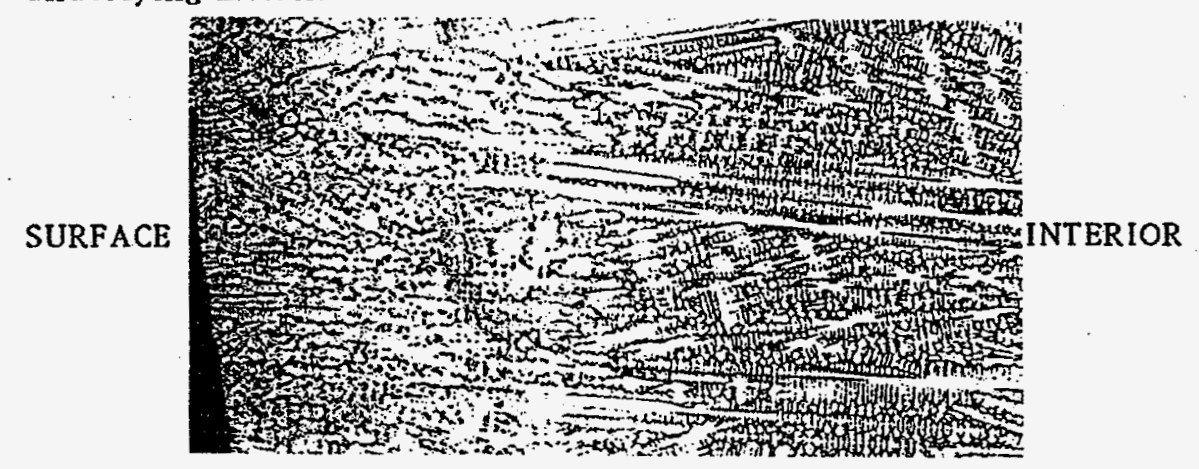

Figure 6. Macrostructural Gradient Associated with Near Surface Chromium Depletion in As-cast Ingot, $50 \mathrm{X}$

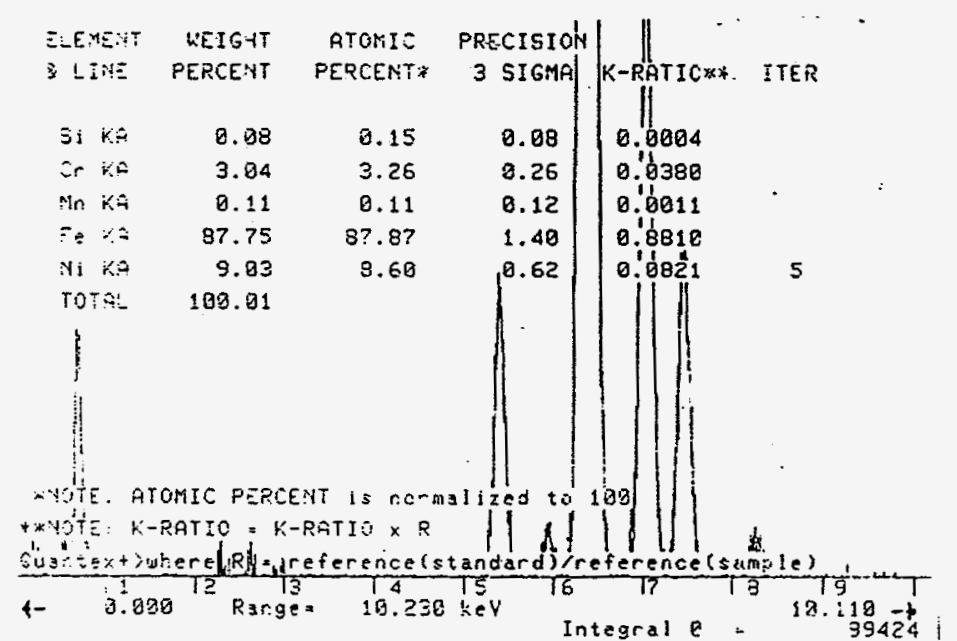

Figure 7. Energy Dispersive Analysis of $X$-rays Created during SEM Examination of Surface of Ingot 
The replacement of graphite molds with alumina crucibles eliminated, as expected, the unacceptable carbon uptake. This increased the ductility of the ingot and provided as-cast samples that were cold rolled to greater than ninety percent reduction in thickness. The rolling process, which was followed by a surface grinding operation to eliminate incipient edge cracks at several stages in the rolling process. elongated and broke-up the as-cast microstructure (Figure 8 ).

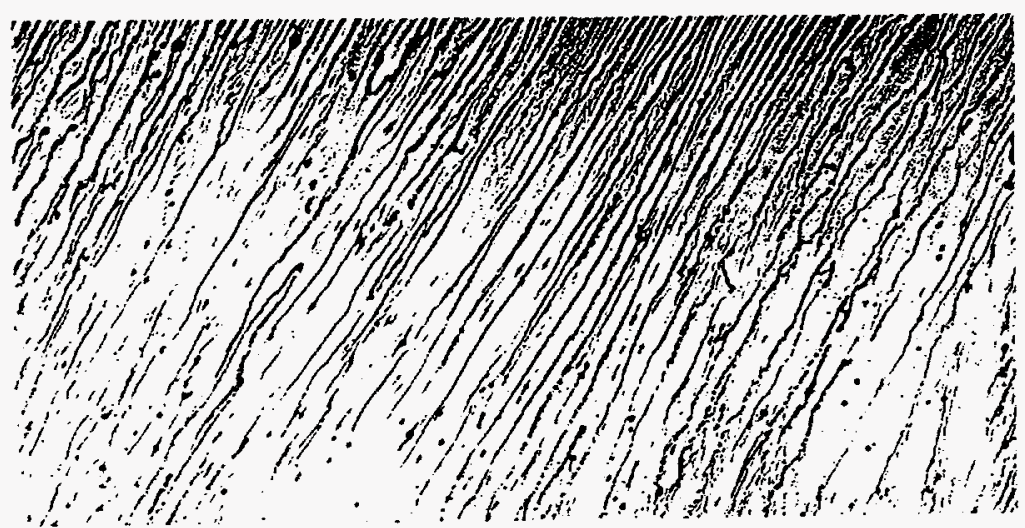

Figure 8. Microstructure of Ingot after Cold Rollong to $80 \%$ Reduction in Thickness. $250 \mathrm{X}$

Annealing of the cold rolled ingot caused recrystallization and provided a microstructure typical of recrystallized, wrought austenitic stainless steel products (Figure 9).

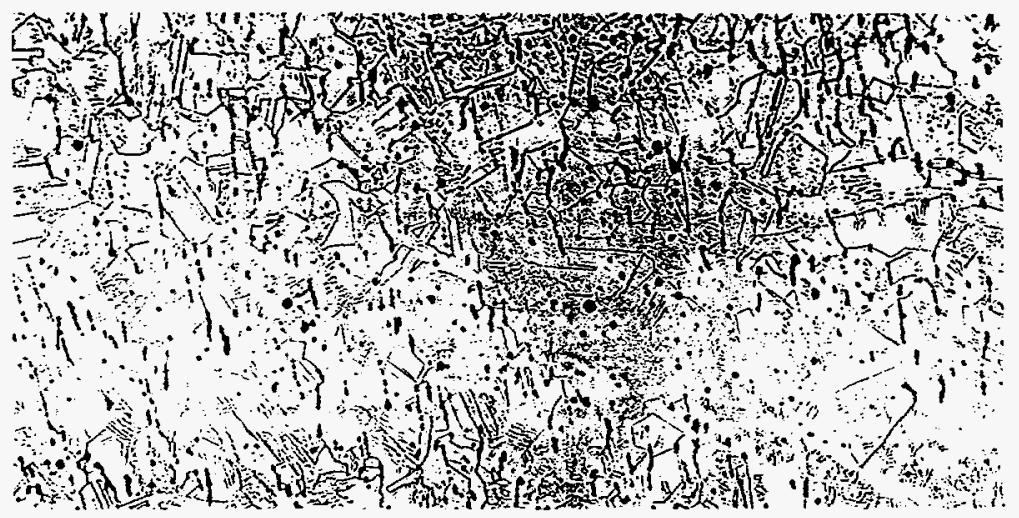

Figure 6. Recrustallized Microstructure After the Cold Rolled Section was Annealed at $1000^{\circ} \mathrm{C}$ for Two Hour. $250 \mathrm{X}$ 


\section{CONCLUSIONS}

Laboratory scale experiments have demonstrated that Type 304 stainless steel which has been contaminated with radionuclides can be recycled for potential reuse. Decontamination, melting, casting, rolling and heat treatment experiments with previously contaminated feed stock and non-contaminated control samples have provided "recycled" steel which has the $18 \% \mathrm{Cr}-8 \% \mathrm{Ni}$ composition and microstructures similar to commercial grade alloys.

\section{REFERENCES}

1) M. Laser, "Melting and Recycling Waste from Decom" Nuclear Europe Worldscan, Vol. XIV, No. 1-2, page 58, 1994

2) L. A. Nieves of Argonne National Laboratory, "Evaluation of Radioactive Scrap Metal Recycling" May 19-20, 1993 Conference/Workshop on Recycle of Radioactively Contaminated Metals, Augusta, GA, Copies of slides from Presentation available from Westinghouse Savannah River Company

3) G. F. Kessinger of Westinghouse Idaho Nuclear Company, "W INCO Metal Recycle Program", ibid Reference 2

4) D. E. Raw1, Jr., S. L. West, D. A. Wheeler and M. R. Louthan, Jr., "Defect Cheracterization in Pipe-to-Pipe Welds in Large Diameter Stainless-Steel Piping" Materials Characterization, Vol. 33, p. 155,1994

5) M. R. Louthan, Jr., S. L. West and D. Z. Nelson, "Inspection Indications, Stress Corrosion Cracks and Repair of Process Piping in Nuclear Materials Production Reactors" p. 314 in Maintenance and Repair Welding in Power plants, A merican Welding Society, Miami, FL, 1992

6) S. A. Worcester, T. G. Twidwell, D. J. Paolini, T. A. Weldon and R. E. Mizia, "Decontamination of Metals by Melt Refining/Slagging" presented to American Vacumn Society Conference on Liquid Metal Processing, Santa Fe, MN, September 11-14, 1994 